\title{
The occult spread of the invasive brown marmorated stink bug, Halyomorpha halys (Stål, 1855) (Hemiptera Pentatomi- dae), in Sardinia (Italy)
}

\author{
Laura Loru', Piera M. Marras²*, Mauro Nannini ${ }^{3}$ \& Roberto A. Pantaleoni ${ }^{4}$
}

\begin{abstract}
${ }^{1}$ Istituto di Ricerca sugli Ecosistemi Terrestri, Consiglio Nazionale delle Ricerche (IRET-CNR), Traversa la Crucca 3, Regione Baldinca, 07100 Li Punti, Sassari, Italy; e-mail: laura.loru@cnr.it

${ }^{2}$ Servizio Ricerca nell’Arboricoltura, Agris Sardegna, S.p. Sorso-Li Pidriazzi 9, 07100 Sassari, Italy; e-mail: pmarras@ agrisricerca.it

${ }^{3}$ Servizio Ricerca Studi ambientali, Difesa delle Colture e Qualità delle Produzioni, Agris Sardegna, Viale Trieste 111, 09123 Cagliari, Italy; e-mail: mnannini@agrisricerca.it

${ }^{4}$ Dipartimento di Agraria, sezione di Entomologia, Università degli Studi di Sassari, Viale Italia 39, 07100 Sassari, Italy; email: pantaleo@uniss.it

${ }^{*}$ Corresponding author
\end{abstract}

\begin{abstract}
The invasive brown marmorated stink bug, Halyomorpha halys (Stål, 1855) (Hemiptera Pentatomidae), was recorded in autumn 2018 in Sassari (northern Sardinia, Italy), after a previous finding in Cagliari (over $200 \mathrm{~km}$ away in southern Sardinia) in autumn 2016. It is not clear whether the species has already spread throughout the Sardinia or whether the sighting in the North of Sardinia is due to a second introduction. However, it is usual for this species to have a long period with low population level after its first introduction into a new area. The presence of this very polyphagous alien species is a serious hazard for Sardinian agriculture.
\end{abstract}

KEY WORDS Alien insects; nuisance urban pest; agricultural pest; Italy; Europe.

Received 20.12.2018; accepted 27.12.2018; printed 30.12.2018; published online 07.01.2019

\section{INTRODUCTION}

The Hemiptera Pentatomidae Halyomorpha halys (Stål, 1855), known as the brown marmorated stink bug, is native to Asia, where it is considered a nuisance pest in urban areas due to its overwintering in buildings, and an agricultural pest on fruits and seeds (Lee et al., 2013). In the last two decades it is become invasive in North America and Europe, has been become established in Chile, near Santiago, and has been found in shipments from the United States and Asia to New Zealand and Australia. The timing of the invasions and current distribution in Europe have been summarized by Cianferoni et al. (2018).
Its autumnal shelter-seeking behaviour facilitates both the spread across wide geographical areas and the short-range secondary translocations through human activities, and repeated independent introductions are likely (Hamilton et al., 2018; Leskey \& Nielsen, 2018). Current genetic data suggest a mixed origin of both the European (Cesari et al., 2015, 2017) and the West coast of the United States populations (Hamilton et al., 2018).

\section{RESULTS}

Between the 16th October and the 17th December 2018, four findings (five specimens) of H. halys 
were recorded in the city of Sassari (northern Sardinia, Italy) and its surroundings. All the specimens were collected inside buildings, and each was collected (Fig. 1), identified and conserved in the collection of one of the authors (LL) (Table 1). This record is the second in Sardinia (but the first for the North of the island), the previous one regarded two specimens collected in the city of Cagliari in autumn 2016 (Dioli et al., 2016).

No other reports about the presence of this species in Sardinia are known to the authors (Fig. 2). A survey on crops in experimental stations of Agris Sardegna in the neighborhood of Cagliari, Oristano and Sassari during 2018 did not reveal the bug's presence. However, it is not clear whether the species has already spread throughout the Sardinia or it has been introduced more than once and in different locations.

\section{DISCUSSION}

Typically, after the introduction into a new area, this species shows low population levels for a long period. In USA, the first specimens were collected in 1996, but the presence of the species became evident only five years later, and invasive after a decade (Hamilton et al., 2018). On mainland Italy, similarly, the first specimen was collected in 2007 , but only in 2012 was the species extensively detected (Cianferoni et al., 2018).

In its first stages of invasion the species appears to be only an urban pest, because of its overwintering in houses and commercial buildings, whereas the agricultural problems come later. This has been confirmed many times in several countries in North

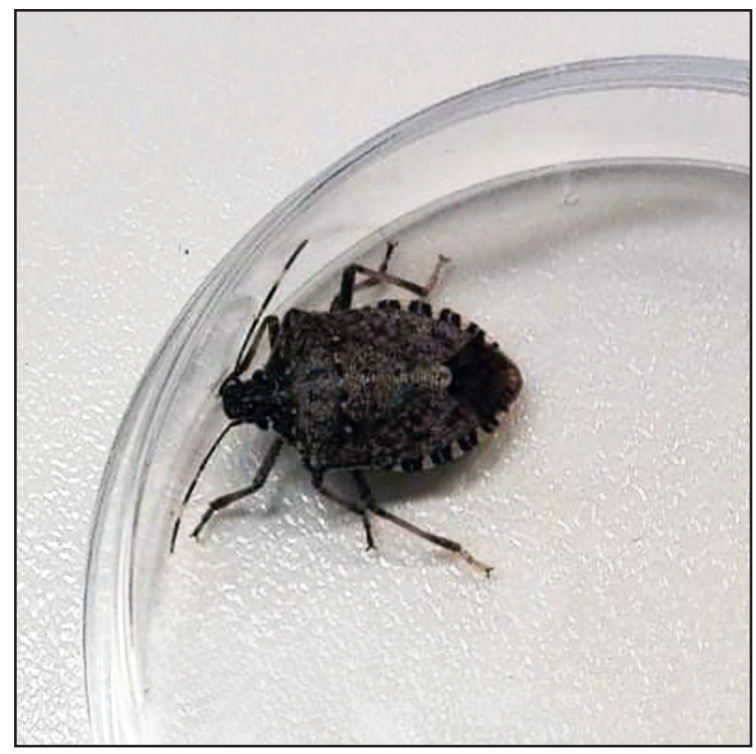

Figure 1. Halyomorpha halys collected inside a building of Sassari city (Italy).

America (Hoebeke \& Carter, 2003; Gariepy et al., 2014) and Europe (for example: Milonas \& Parsinevelos, 2014; Macavei et al., 2015; Rabitsch \& Friebe, 2015, Simov, 2016). The slow and silent spread of this pest should not be underestimated. The brown marmorated stink bug could be a serious threat for Sardinian agriculture.

According to the model proposed by Kriticos et al. (2017), Sardinia, in particular its western coast, appears to be a suitable area for $H$. halys. Three areas - the southern Sulcis, the central Oristano Plain, and the northern Nurra - reach the same suitability level as a large part of northern and central Italy. All three of these areas have very important

\# Collection date Locality Coordinate $\mathbf{N}$ Coordinate $\mathbf{E}$ Specimens Collector

\begin{tabular}{llllccc}
\hline 1 & 16 Oct 2018 & Sassari & 40.72723 & 8.56915 & 2 males & V. Ligios \\
2 & 19 Oct 2018 & Sassari & 40.71679 & 8.57006 & 1 female & V. Ligios \\
3 & 14 Dec 2018 & Li Punti & 40.75490 & 8.49679 & 1 female & G. Medde \\
4 & 17 Dec 2018 & Sassari & 40.72414 & 8.56023 & 1 male & A. Muroni \\
\hline
\end{tabular}




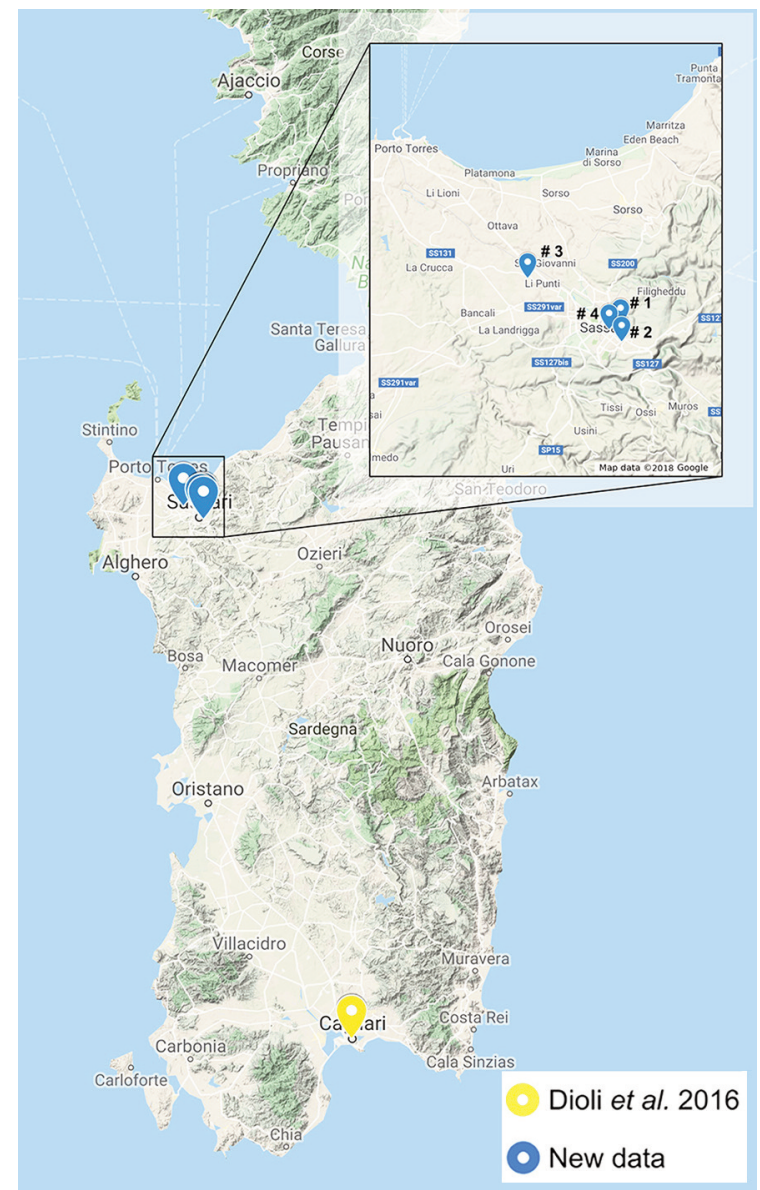

Figure 1. Sites in which Halyomorpha halys was collected in Sardinia (Italy). Numbers refer to the data cited in Table 1.

agricultural productions potentially threatened by the brown marmorated stink bug which is able to damage almost every fruit or seed of agricultural importance (Leskey \& Nielsen, 2018) including rice (Lupi et al., 2017). Moreover, this bug is also able to become a key pest of additional crops in invaded countries (Lee et al., 2013).

\section{REFERENCES}

Cesari M., Maistrello L., Piemontese L., Bonini R., Dioli P., Lee W., Park C.G., Partsinevelos G.K., Rebecchi L. \& Guidetti R., 2017. Genetic diversity of the brown marmorated sting bug Halyomorpha halys in the invaded territories of Europe and its patterns of diffusion in Italy. Biological Invasions, 20: 10731092. DOI: $10.1007 / \mathrm{s} 10530-017-1611-1$

Cesari M., Maistrello L., Ganzerli F., Dioli P., Rebecchi
L. \& Guidetti R., 2015. A pest alien invasion in progress: potential pathways of origin of the brown marmorated stink bug Halyomorpha halys populations in Italy. Journal of Pest Science, 88: 1-7. DOI: 10.1007/s10340-014-0634-y

Cianferoni F., Graziani F., Dioli P. \& Ceccolini F., 2018. Review of the occurrence of Halyomorpha halys (Hemiptera: Heteroptera: Pentatomidae) in Italy, with an update of its European and World distribution. Biologia, 73: 599-607. DOI: 10.2478/s11756-0180067-9

Dioli P., Leo P. \& Maistrello L., 2016. Prime segnalazioni in Spagna e in Sardegna della specie aliena Halyomorpha halys (Stål,1855) e note sulla sua distribuzione in Europa (Hemiptera, Pentatomidae). Revista gaditana de Entomologia, 7: 539-548.

Gariepy T.D., Fraser H. \& Scott-Dupree C.D., 2014. Brown marmorated stink bug (Hemiptera:Pentatomidae) in Canada: recent establishment, occurrence, and pest status in southern Ontario. The Canadian Entomologist,146: 579-582. DOI: 10.4039/ tce.2014.4

Hamilton G.C., Ahn J.J., Bu W., Leskey T.C., Nielsen A.L., Park Y.L., Rabitsch W. \& Hoelmer K.A., 2018. Halyomorpha halys (Stål). In: McPherson J.E., Invasive Stink Bugs and Related Species (Pentatomoidea) Biology, Higher Systematics, Semiochemistry, and Management. Taylor \& Francis, Boca Raton, pp. 243-292.

Hoebeke R.E. \& Carter M.E., 2003. Halyomorpha halys (Stål) (Heteroptera: Pentatomidae): a polyphagous plant pest from Asia newly detected in North America. Proceedings of the Entomological Society of Washington, 105: 225-237.

Kriticos D.J., Kean J.M., Phillips C.B., Senay S.D., Acosta H. \& Haye T., 2017. The potential global distribution of the brown marmorated stink bug, Halyomorpha halys, a critical threat to plant biosecurity. Journal of Pest Science, 90: 1033-1043. DOI: 10.1007/s10340-017-0869-5

Lee D.H., Short B.D., Joseph S.V., Bergh J.C. \& Leskey T.C., 2013. Review of the Biology, Ecology, and Management of Halyomorpha halys (Hemiptera: Pentatomidae) in China, Japan, and the Republic of Korea. Environmental Entomology, 42: 627-641. DOI: $0.1603 / \mathrm{EN} 13006$

Leskey T.C. \& Nielsen A.L., 2018. Impact of the Invasive Brown Marmorated Stink Bug in North America and Europe: History, Biology, Ecology, and Management. Annual Review of Entomology, 63: 599-618. DOI: 10.1146/annurev-ento-020117-043226

Lupi D., Dioli P. \& Limonta L., 2017. First evidence of Halyomorpha halys (Stål) (Hemiptera Heteroptera, Pentatomidae) feeding on rice (Oryza sativa L.). Journal of Entomological and Acarological Research, 49: 67-71. DOI: 10.4081/jear.2017.6679 
Macavei L.I., Bâetan R., Oltean I., Florian T., Varga M., Costi E. \& Maistrello L., 2015. First detection of $\mathrm{Ha}$ lyomorpha halys Stål, a new invasive species with a high potential of damage on agricultural crops in Romania. Lucrări Stiintifice, 58: 105-108.

Milonas P.G. \& Partsinevelos G.K., 2014. First report of brown marmorated stink bug Halyomorpha halys Stål (Hemiptera: Pentatomidae) in Greece. Bulletin OEPP/ EPPO Bulletin, 44: 183-186. DOI: 10.1111/ epp.12129
Rabitsch W. \& Friebe G.J., 2015. From the west and from the east? First records of Halyomorpha halys (Stål, 1855) (Hemiptera: Heteroptera: Pentatomidae) in Vorarlberg and Vienna (Austria). Beiträge zur Entomofaunistik, 16: 126-129.

Simov N., 2016. The invasive brown marmorated stink bug Halyomorpha halys (Stål, 1855) (Heteroptera: Pentatomidae) already in Bulgaria. Ecologica Montenegrina, 9: 51-53. 